\title{
Research on the Construction of Courses of Automotive Electronics and Electrical Appliances Based on the Joint Training Mode of Vocational Schools and Applied Undergraduate Courses
}

\author{
Wei Dan ${ }^{1}$, Ren Xian ${ }^{2}$, Ma Qi Hua \\ ${ }^{1}$ Shanghai University of Engineering Science, Shanghai, China \\ 2Shanghai City Science and Technology School, Shanghai, China \\ ${ }^{3}$ Shanghai University of Engineering Science, Shanghai, China \\ Email: weiweidandan@163.com
}

\begin{abstract}
:
With the development of science and technology, automobile technology is increasingly improving in the direction of safety, environmental protection, and energy conservation. Automobile has been transformed from traditional mechanical products into typical mechatronics products. The role of automotive electronic and electrical technology in the production and use of automobiles has become more apparent. Automotive electronics and electrical courses are core courses in the vocational and applied undergraduate joint training model. This paper analyzes the current situation of the course, and puts forward the content of the course construction of automotive electronics and electrical appliances that is suitable for the joint training mode, which has certain guiding significance for the follow-up professional courses.

Keywords:

automotive electronics and electrical appliances; course construction; vocational school and applied undergraduate joint training mode
\end{abstract}

\section{Introduction}

In January 2016, Shanghai University of Engineering Science in China cooperated with Shanghai city science and Technology School (secondary vocational and technical school) to apply for the joint training mode scheme of automobile service engineering major, which has been unanimously approved by Shanghai education assessment experts and enrolled the first batch of students in September 2016. The scheme attempts to explore the road to the cultivation of advanced technical application talents for automotive service engineering through this long-term teaching model.

In recent years, the rapid development of electronic information science and technology has provided the necessary electronic technology foundation for the development of the automotive industry, making the use of automotive technology in the direction of safety, environmental protection and energy saving. The automobile has changed from traditional mechanical products to typical mechatronics products, automotive electronic and electrical technology has gradually become one of the characteristics of automotive high-tech, which requires modern automotive use, maintenance, testing and maintenance technicians should develop toward the direction of mechatronics. Based on the society's demand for automotive professional skill talents, the teaching of "automotive electronics" and "automotive electronics and electrical appliances" as the basic course of automotive majors should be further emphasized and strengthened. The Shanghai University of Engineering Science automotive electronics and electrical appliances and the Shanghai city science and Technology School automotive electrical and electronic courses are interlinked and need to build a course system. 


\section{Review of Literature}

\section{Current status of automotive electronics and electrical courses}

Automotive electronics is an important course content for both higher vocational and undergraduate courses. Before the joint training, the secondary vocational course is to learn "automotive electrical and electronic". The teaching requirements involve the basic knowledge of electrical and electronic circuits and the basic operating skills of circuit detection. However, due to class hours and student characteristics, the content is not deeply involved. At the same time, in order to avoid duplication and partial blanks of the course content, it is necessary to carry out course reform and construction of "automotive electronics and electrical appliances".

The original automotive electrical and electronic technology emphasizes the systematic nature of subject knowledge. It is an independent teaching system for both secondary vocational and undergraduate teaching. The purpose of the project is to connect with the secondary vocational and undergraduate courses through course construction, making it a large knowledge system. The secondary vocational stage takes "necessary and sufficient" as the degree, pays attention to the foundation, emphasizes practicality, rationally selects teaching content, and reduces the starting point of knowledge. In the way of task guidance and case analysis, the basic skills of automobile maintenance electrician are strengthened. Undergraduate stage, on the basis of secondary vocational education, deepen theoretical knowledge and practice, so that automotive electrical and electronic learning can be further improved and students' interest in learning can be improved. To develop students' ability to analyze and solve problems and improve their employability.

\section{a. Advantages of this course}

1) Through the combination of traditional teaching, multimedia and online platforms, this teaching method is convenient for students to learn inside and outside the classroom and understand the difficult points, and also deepen the communication between teachers and students.

2) Under the promotion of research projects related to the development of automobile safety auxiliary control systems in cooperation with domestic automobile manufacturing enterprises, scientific research results are introduced into the teaching process, and theory and practice are closely combined.

3) A team of high-quality teachers with multidisciplinary knowledge background based on young and middle-aged teachers has been formed.

\section{b. Insufficient course}

1) Modern automotive electric and electronic technology is developing rapidly, and it is necessary to continuously update teaching content.

2) After many years of teaching, it is found that the course of automotive electrics and electronics is a frontier subject with interdisciplinary disciplines. Teaching knowledge involves a wide range of areas, prone to the phenomenon that the teaching is not deep enough. 


\section{Discussion}

\subsection{The specific construction content of the course construction project}

This course focuses on cultivating students' basic knowledge of automotive electrical and electronic theory, focusing on the theoretical basis and the training process, and organizing courses through practical tasks, work processes and work situations. Let students build knowledge and professional skills in their professional actions. Develop students' professional, methodological, and social skills to equip students with the comprehensive professional skills necessary for future work (Zhang Yan \& Du Hongle 2019), (Monika Knassmüller \& Sylvia Veit 2016).

This course is based on the work process-oriented course method, the development of the corresponding learning situation, formulates course standards and designs teaching units. This course is mainly carried out in the professional training room. The purpose is to combine teaching, learning and training, so that students have more hands-on operation time, master the content from the perspective of use, and lay the foundation for the subsequent skills development.

\section{a. Integration of theoretical knowledge into project learning}

In order to avoid boring learning of basic knowledge, the study of theoretical knowledge is transferred into the project. The project contents of offering automotive electrical and electronic courses are shown in table 1, and the project 1-6 study in the secondary vocational stage, and project 7 and 8 study in the university stage.

Table 1. Automotive electrical and electronic basic course content standards and requirements

\begin{tabular}{|c|c|c|c|c|}
\hline $\begin{array}{l}\text { Project } \\
\text { number }\end{array}$ & $\begin{array}{l}\text { Learning unit } \\
\text { (module) }\end{array}$ & $\begin{array}{l}\text { Knowledge } \\
\text { requirement }\end{array}$ & $\begin{array}{l}\text { Ability } \\
\text { demanded }\end{array}$ & $\begin{array}{l}\text { Ability } \\
\text { training }\end{array}$ \\
\hline 1 & $\begin{array}{l}\text { Project 1: Safety } \\
\text { electricity }\end{array}$ & $\begin{array}{l}\text { 1: Understand the form of } \\
\text { electric shock } \\
\text { 2: Understand safety } \\
\text { electricity considerations } \\
\text { 3: Grasp the common } \\
\text { sense of electric fire } \\
\text { extinguishing } \\
\text { 4: Master the basics of } \\
\text { electric shock emergency }\end{array}$ & $\begin{array}{l}\text { 1: Measures to } \\
\text { correctly select } \\
\text { safe use of } \\
\text { electricity } \\
\text { 2: Give correct } \\
\text { first aid after } \\
\text { electrocution }\end{array}$ & $\begin{array}{l}\text { 1: Basic } \\
\text { knowledge of } \\
\text { electricity }\end{array}$ \\
\hline 2 & $\begin{array}{l}\text { Project 2: Basic } \\
\text { knowledge of } \\
\text { DC circuits }\end{array}$ & $\begin{array}{l}\text { 1: Understand the } \\
\text { composition and state of } \\
\text { the circuit } \\
\text { 2: Master the basic laws of } \\
\text { the circuit } \\
\text { 3: Master the basics of } \\
\text { series and parallel circuits }\end{array}$ & $\begin{array}{l}\text { 1: Skilled in } \\
\text { geometric } \\
\text { calculation of } \\
\text { voltage, current, } \\
\text { resistance and } \\
\text { power } \\
\text { 2: Proficiency in } \\
\text { geometric } \\
\text { operations of } \\
\text { physical quantities } \\
\text { in series-parallel } \\
\text { circuits }\end{array}$ & $\begin{array}{l}\text { 1: Basic } \\
\text { knowledge of } \\
\text { electricity }\end{array}$ \\
\hline 3 & $\begin{array}{l}\text { Project 3: } \\
\text { Magnetic Circuit } \\
\text { and } \\
\text { Electromagnetic }\end{array}$ & $\begin{array}{l}\text { 1: Understand the } \\
\text { magnetic effects of current } \\
\text { and the law of } \\
\text { electromagnetic induction }\end{array}$ & $\begin{array}{l}\text { 1: Proficiency in } \\
\text { the use of } \\
\text { electromagnetic } \\
\text { induction law to }\end{array}$ & $\begin{array}{l}\text { 1: Connection of } \\
\text { car horn circuits }\end{array}$ \\
\hline
\end{tabular}


Britain International of Humanties and Social Sciences (BIoHS) Journal

ISSN: 2685-3868 (Online), 2685-1989 (Print)

Vol. 2, No. 1, February 2020, Page: 1-8

\begin{tabular}{|c|c|c|c|c|}
\hline & $\begin{array}{l}\text { Device } \\
\text { Applications }\end{array}$ & $\begin{array}{l}\text { 2: Master the working } \\
\text { principle of the relay } \\
\text { 3: Master the working } \\
\text { principle of the } \\
\text { transformer }\end{array}$ & $\begin{array}{l}\text { analyze the } \\
\text { working principle } \\
\text { of relays } \\
\text { 2: Analyze how } \\
\text { the transformer } \\
\text { works }\end{array}$ & \\
\hline 4 & $\begin{array}{l}\text { Project 4: Use of } \\
\text { instruments and } \\
\text { meters }\end{array}$ & $\begin{array}{l}\text { 1: Master the use of digital } \\
\text { multimeters } \\
\text { 2: Master the use of } \\
\text { automotive digital } \\
\text { multimeters }\end{array}$ & $\begin{array}{l}\text { 1: Correctly use } \\
\text { digital multimeters } \\
\text { to measure } \\
\text { physical quantities } \\
\text { such as voltage, } \\
\text { resistance, current, } \\
\text { capacitance, etc., } \\
\text { and accurately read }\end{array}$ & $\begin{array}{l}\text { 1: Measurement } \\
\text { of various group } \\
\text { values of } \\
\text { resistance, DC } \\
\text { voltage, and AC } \\
\text { voltage }\end{array}$ \\
\hline 5 & $\begin{array}{l}\text { Project 5: } \\
\text { manufacture of } \\
\text { automotive } \\
\text { transistor analog } \\
\text { circuit }\end{array}$ & $\begin{array}{l}\text { 1: Learn to use an electric } \\
\text { soldering iron } \\
\text { 2: Learn about } \\
\text { semiconductor knowledge } \\
\text { 3: Master the identification } \\
\text { and detection of resistors } \\
\text { and capacitors } \\
\text { 4: Master the principle of } \\
\text { flasher and voltage } \\
\text { regulator }\end{array}$ & $\begin{array}{l}\text { 1: Measuring the } \\
\text { parameters of the } \\
\text { diode and triode } \\
\text { with a multimeter } \\
\text { 2: Differentiating } \\
\text { the type of } \\
\text { capacitor and } \\
\text { measuring the } \\
\text { parameters of the } \\
\text { capacitor }\end{array}$ & $\begin{array}{l}\text { 1: Verify the } \\
\text { unidirectional } \\
\text { conductivity of } \\
\text { the diode } \\
\text { 2: Determine the } \\
\text { three pins of the } \\
\text { triode and } \\
\text { measure the } \\
\text { magnification }\end{array}$ \\
\hline 6 & $\begin{array}{l}\text { Project 6: } \\
\text { Automotive } \\
\text { Circuit Reading }\end{array}$ & $\begin{array}{l}\text { 1: Learn the basics of } \\
\text { automotive circuit } \\
\text { harnesses } \\
\text { 2: Recognize component } \\
\text { symbols, code numbers, } \\
\text { and location status } \\
\text { 3: Master the working } \\
\text { process of the lighting } \\
\text { circuit } \\
\text { 4: Learn to read other } \\
\text { simple car circuits }\end{array}$ & $\begin{array}{l}\text { 1: Simple } \\
\text { troubleshooting of } \\
\text { lighting circuits }\end{array}$ & $\begin{array}{l}\text { 1: Lighting circuit } \\
\text { troubleshooting }\end{array}$ \\
\hline 7 & $\begin{array}{l}\text { Project 7: } \\
\text { Application of } \\
\text { Digital Circuits } \\
\text { in Modern } \\
\text { Automobiles }\end{array}$ & $\begin{array}{l}\text { 1: Master the conversion } \\
\text { and operation of the } \\
\text { number system } \\
\text { 2: Understand the } \\
\text { functions of counters, } \\
\text { decode and display devices }\end{array}$ & $\begin{array}{l}\text { 1: Convert } \\
\text { between number } \\
\text { systems }\end{array}$ & $\begin{array}{l}\text { 1: automobile } \\
\text { water tank water } \\
\text { level alarm } \\
\text { 2: automobile } \\
\text { door lock control } \\
\text { circuit }\end{array}$ \\
\hline 8 & $\begin{array}{l}\text { Project 8: } \\
\text { Introduction to } \\
\text { Automotive } \\
\text { Microcomputer } \\
\text { Control System }\end{array}$ & $\begin{array}{l}\text { 1: Understand the } \\
\text { advantages of automobile } \\
\text { microcomputer control } \\
\text { 2: Master the classification } \\
\text { of automobile } \\
\text { microcomputer control } \\
\text { 3: Understand the } \\
\text { knowledge of electronic } \\
\text { control units } \\
\text { 4: Master the knowledge } \\
\text { of sensors }\end{array}$ & $\begin{array}{l}\text { 1: Performing } \\
\text { installation, } \\
\text { disassembly testing } \\
\text { and maintenance } \\
\text { of automotive } \\
\text { microcomputer } \\
\text { control 2: } \\
\text { Installation, } \\
\text { disassembly testing } \\
\text { and maintenance } \\
\text { of electronic } \\
\text { control units and } \\
\text { sensors }\end{array}$ & $\begin{array}{l}\text { 1: Installation, } \\
\text { disassembly } \\
\text { testing and } \\
\text { maintenance of } \\
\text { automotive } \\
\text { microcomputer } \\
\text { control } \\
\text { 2: Maintenance } \\
\text { of electronically } \\
\text { controlled } \\
\text { sensors }\end{array}$ \\
\hline
\end{tabular}


Through the systematic design of the whole teaching content, instead of teachers holding hands, students can do it according to the task independently. Through the learning process that practice makes perfect, students gradually complete the complete division of labor, measurement and evaluation (Rohdearni Wati Sipayung 2018). To realize the transfer from knowledge copy to independent learning to the cultivation of innovation ability, and finally to achieve the goal of this course.

\section{1) Cultivate students' practical skills}

Teaching process from simple to complex, such as from the function introduction of digital multimeter to measuring simple components, finally able to judge the performance of the components and extended to the real vehicle measurement, which can make students started as soon as possible, and gradually improve the students' learning interests and comprehensive practice ability, cultivate students practical skills to analyze and solve problems (Rusydi Ananda 2019), (Nga D. Tran, Thanh T. Nguyen and My T.N. Nguyen 2011).

\section{2) Cultivate students' innovation ability based on design}

The teacher carefully designs the teaching content, the student from the knowledge copy, encounters the similar question to search the references, and designs the circuit to carry on the measurement, finally carries on the evaluation according to own measurement result. In solving the problem process independent research, the innovation ability is promoted.

\section{3) Cultivate students' sense of cooperation by taking the team as the unit}

In this process, the consciousness of teamwork and competition is gradually strengthened and layered teaching is applied (Tesfaye Buche Bosha, Desalegn Youpo Ukute 2019). A clear division of responsibilities within the team members, each department, there are some excellent comprehensive performance, each group of selfstudy ability, practice ability and analysis ability of students, use their strengths to drive this group of corresponding contents of the other students in learning, assessment, and common progress, to expand the students practice, increase proficiency and innovation consciousness. Students in the training through careful thinking and intense discussion, finally for the common goal, to form a unified thought to work together.

\section{4) Take the position as the goal to cultivate students' professional ability}

Teaching organization form and the professional post, teaching means and methods more authenticity, convert all kinds of professional ability to separate the typical work tasks, and tasks are integrated, deepen students' understanding of professional post and identity, effectively improve the students' learning interest and learning enthusiasm, improve the students' comprehensive ability and professional ability. Teachers become the guide, students as the main body of the activity, in different stages of learning, with different identity to complete different posts work and learning content, and jointly participate in and discuss to solve practical problems.

\section{b. Project content in the "module" mode}

The teaching introduction module refers to a teaching unit, and each teaching module has clear teaching objectives, complete teaching content and determined assessment standards. The "module" model adopted by automotive electrical and electronic technology should be based on the ability of training, and the "capability module" with the cognitive ability and activity ability that should be possessed in the work related to automobile service engineering. 
First of all, the text structure of the original course is knowledge-centered and the modules are independent of each other (Lu Lili, Jiang Jiaolian, Liao Chanjuan, Su Long, Yang Jian(2019). The new course should attach importance to the imparting of knowledge. In addition, the flexible application of knowledge and skills should be emphasized. The modules are not closely connected and can be independently become a teaching unit. Secondly, the content in the module is written in a way that combines theory with practice. The new course is not like the traditional structure of the text which is knowledge before skill, which separates knowledge from skill. The module teaching breaks the boundaries between theoretical and practical lessons. At the same time, we should deal with the relationship between necessary knowledge and expanding knowledge. Modular teaching materials take quality and ability as the basis for module division, which may lead to incomplete and unsystematic knowledge structure. In terms of content design, the undergraduate stage will focus on the deepening and improvement of the overall knowledge structure system. The advantages of the joint training model based on vocational schools and applied undergraduates are highlighted.

\subsection{Construction of teaching method reform}

a. This course has a strong practicality, so it is necessary to improve teaching methods in the teaching process, take students as the main body and fully mobilize their initiative and enthusiasm in learning according to the rules and characteristics of students' learning. In terms of the organization of course content, it is suggested to choose appropriate products as project carriers, and integrate difficult contents into corresponding project tasks, so as to combine theory with practice and help students understand course content. In the teaching method, can use the heuristic teaching, to the key theory content should explain carefully, the practice part should demonstrate the operation, and encourages the student to study independently and the class discussion, combines the example to explain, enhances the student's study interest and the study ability (Leathem, T., Hillesheim, C., Coley, A. and McGregor, S 2019), (Philips, K(1977).

b. Establish after-class interaction and question-answering channels based on WeChat platform to solve students' doubts. By timely sharing cutting-edge knowledge related to teaching with students, students can learn independently, mobile learning, and increase after-class interaction with students to arouse their enthusiasm for learning.

c. In the classroom teaching, we should make full use of the material objects, video, slides and other modern teaching means, improve the classroom teaching effect, enhance students' perceptual understanding.

d. In the teaching process, we can make full use of the network function to guide students to inquire the network data, encourage students to find the appropriate production examples and experience independently, and further expand the teaching content.

e. This course is also a professional course with strong practicality. We should try our best to create opportunities for students to visit enterprises, and make every effort to provide students with sufficient hands-on opportunities, so that students can find laws in the process of practice and observation, and improve their ability to analyze problems.

f. Faculty reform

In order to realize the integrated training, the two universities have equipped the pilot majors with professional teachers. In the aspect of automotive electricians and electronics teaching, there are two teaching teams for students in the secondary vocational stage (Chairoel Idris, Mesiono 2019). The other one is the skilled craftsman of the automobile enterprise introduced from outside the organization, who serves as the practical training instructor, altogether 2 people. At the undergraduate stage, a backbone teacher team composed of subject leaders and professional teaching teams with high quality, strong ability and excellent skills has been formed in the construction 
of automotive electrical and electronic courses. Among them, the proportion of teachers with high professional titles is more than $35 \%$, that of double-qualified teachers is more than $75 \%$, and that of doctors (reading) is more than $85 \%$. Each year, the average number of teachers in teaching and professional training reaches 3 person-times per year. The level of teachers improves the core combat effectiveness of professional development.

g. Reform assessment method

1) Assessment method

It is suggested to adopt a combination of theory and practice, and take a comprehensive examination of the study of theoretical knowledge by combining attendance, classroom questions, after-school assignments, and unit small tests. During the practice process, the class can be divided into several groups. The group leader will lead the group members to complete the practical training task, and organize the group to fill in the practical training report. Finally, teachers evaluate students' performance comprehensively according to their theoretical and practical achievements.

2) Grade evaluation

Highlight the combination of theory and practice, with emphasis on students' practical application level. The new assessment method is as follows:

Theoretical score $=$ attendance $* 10 \%+$ classroom questions $* 40 \%+$ assignments $* 30 \%+$ unit small test $* 20 \%$;

Practice score $=$ training performance $* 70 \%+$ training report $* 30 \%$;

Comprehensive score $=$ theoretical score $* 40 \%+$ practical score $* 60 \%$.

\section{Conclusion}

This paper analyzes the current situation of automotive electronics and electrical course and puts forward the content of automotive electronics and electrical course construction which is suitable for this course. And proposed some reform means in teaching methods, teachers, assessment methods and other aspects. This will lay a foundation for the development of the following courses.

\section{Acknowledgement}

The paper is supported by the fifth batch Shanghai municipal university applied undergraduate "Automobile service engineering" pilot specialty construction (Shanghai education commission, high [2017] no.79); And Shanghai high level vocational school and applied undergraduate pilot joint training mode construction project (Shanghai education commission [2018] no. 37) .

\section{References}

Zhang Yan, Du Hongle. (2019). Exploration and practice of pluralistic practical teaching mode. Microcomputer Application, 2019(09):44-46+52.

Lu Lili, Jiang Jiaolian, Liao Chanjuan, Su Long, Yang Jian. (2019). Discussion on the reform of safety engineering experiment teaching. University Education, 2019(10):72-75.

Leathem, T., Hillesheim, C., Coley, A. and McGregor, S. (2019). Student and teacher perspectives on a multi-disciplinary collaborative pedagogy in architecture and construction, Higher Education, Skills and Work-Based Learning, 2019, Vol. 9 No. 1, pp. 121-132. 
Philips, K. (1977). A course on decision-making in the public service, Industrial and Commercial Training, 1977, Vol. 9 No. 5, pp. 203-206.

Rohdearni Wati Sipayung. (2018). Improving Students' Achievement in Reading Descriptive Text through Reciprocal Teaching Strategy, Budapest International Research and Critics in Linguistics and Education (BirLE) Journal, 2018, Vol. 1, No. 1, pp. 29-48.

Chairoel Idris, Mesiono. (2019). The Effectiveness of Madrasah Head Leadership Competency in Increasing Educational Quality in Madrasah Tsanawiyah Private Vocational School, Al Manar Medan. Britain International of Humanities and Social Sciences, vol. 1, no. 2, October 2019, pp. 174-180.

Rusydi Ananda. (2019). Blended Learning Model at Learning Evaluation Course (R \& D research). Budapest International Research and Critics in Linguistics and Education (BirLE Journal), vol. 2, no. 2, 2019, 399-406.

Tesfaye Buche Bosha, Desalegn Youpo Ukute. (2019). An Exploration into Teachers' Perceptions towards the challenges of Teaching Reading Skills using Communicative Language Teaching Approach: Focus on Wolaita Sodo Preparatory School. Britain International of Linguistics, Arts and Education, Vol. 1, no. 1, July 2019, pp. 1-8.

Nga D. Tran, Thanh T. Nguyen and My T.N. Nguyen. (2011). The Standard of Quality for HEIs in Vietnam: a step in the right direction? Quality Assurance in Education, vol. 19 no. 2, 2011, pp.130-140.

Monika Knassmüller and Sylvia Veit. (2016). Institutional Constraints of Experimental Learning Formats in Professional PA Master Programmes. Developing Public Managers for a Changing World. 2016. 